\title{
RESPONSE OF BROWN MUSSEL, PERNA INDICA, TO ELEVATED TEMPERATURES IN RELATION TO POWER PLANT BIOFOULING CONTROL
}

\author{
S. RAJAGOPAL, ${ }^{1 *}$ K. V. K. NAIR ${ }^{2}$ and A. AZARIAH ${ }^{1}$ \\ ${ }^{1}$ Department of Zoology, University of Madras, Guindy Campus, Madras 600025 and ${ }^{2}$ Water and Steam \\ Chemistry Laboratory (Applied Chemistry Division, BARC), Indira Gandhi Centre for Atomic Research, \\ Kalpakkam 603 102, India
}

(Received 14 November 1994; accepted in revised form 14 January 1995)

\begin{abstract}
Results of a study on lethal and sublethal responses of different size groups of the tropical brown mussel, Perna indica, when exposed to different temperatures are presented.

2. Exposure to a temperature of $38^{\circ} \mathrm{C}$ showed $100 \%$ mortality of $9 \mathrm{~mm}$ size group mussels in $120 \mathrm{~min}$.

3. Mortality was dependent on age (size) of the mussels, young ones being more susceptible than older ones.

4. All size groups showed a progressive reduction in physiological activities such as filtration rate, foot activity and byssus thread production when temperature was increased from $30^{\circ} \mathrm{C}$.

5. This study suggests that heat treatment is an attractive alternative to chlorination for mussel fouling control in tropical power stations.
\end{abstract}

Key Word Index: Power station; Perna indica; fouling control; heat treatment; mortality; filtration rate; foot activity; byssus thread production

\section{INTRODUCTION}

For the economical and safe operation of a nuclear power plant, an uninterrupted supply of cooling water to the condensers is essential (Neitzel et al., 1984). However, in seawater-based cooling systems, marine life associated with the incoming water can interfere with the smooth operation of the power plant (Rajagopal, 1991). Extensive growth of biofouling in the seawater cooling circuits can cause a reduction in flow rates (Jenner and JanssenMommen, 1993) and blockage of condenser tubes (Imbro and Gianelli, 1982).

Madras Atomic Power Station (MAPS) is situated at Kalpakkam $\left(12^{\circ} 33^{\prime} \mathrm{N}\right.$ and $\left.80^{\circ} 11^{\prime} \mathrm{E}\right)$, on the east coast of India. MAPS experienced a serious flow blockage in 1987 due to the extensive growth of mussels, Perna indica Kuriakose and Nair and Perna viridis (L.), in the cooling water system (Rajagopal et al., 1991a) and this frequently resulted in station outages (Nair, 1990). Chlorination is used at MAPS to control mussel fouling. However, killing of

*To whom correspondence should be addressed, at Department of Aquatic Ecology, Faculty of Science, University of Nijmegen, Toernooiveld, 6525 ED Nijmegen, The Netherlands. established mussel communities, such as those in the MAPS tunnel, requires continuous doses of chlorine (Rajagopal et al., 1991b). This leads to the question of environmental safety, as chlorine has been reported to be toxic to non-target organisms (Brungs, 1977; Smith and Kretschner, 1984; Jenner, 1985). Moreover, the failure of chlorine to control mussel settlement and growth, despite its continuous use in cooling waters, has been reported from various power stations (Jenner, 1983; Strauss, 1989). However, this is likely to be a failure in the application regime.

Heat treatment for mussel control in power plants has received some attention in recent years (Wright et al., 1983; Claudi and Mackie, 1994). In this method, the heated effluent from power plants, instead of being discharged, is recirculated through the cooling conduits. Therefore, it is highly economical and is increasingly employed in new plants (Jenner, 1982). However, the method also has certain problems in that the application involves a certain level of production penalty for the power plant. Moreover, the heat treatment method would require major design modifications of the cooling system for already operating plants; it is often expensive or technically difficult (Burton and Liden, 1978). A few 
power plants in The Netherlands and U.S.A. have been successfully using heat treatment as a means to control mussel fouling (Graham et al., 1975; Jenner and Janssen-Mommen, 1993). Heat treatment also has potential for the control of mussels in power stations in tropical waters, but there are hardly any data on the response of the brown mussel, $P$. indica, one of the most important fouling species in Indian coastal power stations (Rajagopal et al., 1991a), to heat treatment. Therefore, experiments have been carried out to study lethal and sublethal responses of brown mussels to varying degrees of heat treatment. It is expected that the results will allow optimization of the techniques, so that maximum control could be achieved with a minimum of financial cost and environmental impact.

The present study focuses on the responses of different size groups of $P$. indica to different temperatures.

\section{MATERIALS AND METHODS}

The response of $P$. indica to different temperatures was studied using mussels collected from the coastal waters near the MAPS intake area. In the laboratory, the mussels were acclimated in seawater aquarium tanks $\left(34.1 \pm 0.6 \%\right.$ salinity and $29.8 \pm 0.7^{\circ} \mathrm{C}$ temperature) for 2 days. Based on the shell length (Rajagopal, 1991), mussels were sorted out into five size groups viz $9 \mathrm{~mm}$ (1 month old), $18 \mathrm{~mm} \mathrm{(3}$ months), $25 \mathrm{~mm}$ (6 months), $31 \mathrm{~mm}$ (9 months) and $36 \mathrm{~mm}$ (12 months).

\section{Mortality}

Four size groups of mussels were tested for 7 different target temperatures $\left(38-44^{\circ} \mathrm{C}\right.$, at $1^{\circ} \mathrm{C}$ intervals). Preliminary experiments had shown that large mussels took about $3 \mathrm{~h}$ to attain $100 \%$ mortality at $38^{\circ} \mathrm{C}$. Since $3 \mathrm{~h}$ is approximately the maximum practical duration for which heat treatment could be done in actual utility systems (Jenner, 1982), experiments below $38^{\circ} \mathrm{C}$ were not included. Factors which may affect temperature tolerance such as salinity and dissolved oxygen were kept as stable as possible in each experiment, 33.8-34.3\% and $5.9-6.3 \mathrm{mg} / 1$, respectively. The experiments were carried out using an ultrachriostat (ISSREF, cat. no. IRO 017), following procedures outlined by Sasikumar et al. (1992). The temperature was raised at the rate of $0.1^{\circ} \mathrm{C} / \mathrm{min}$ from $30^{\circ} \mathrm{C}$. The rate of raise was chosen as it corresponds to the rise rates that can be expected during heat treatment in power plants (Jenner, 1982). Mussels failing to respond to external stimuli by closing their shells, were considered dead (Wallis, 1975).

\section{Sublethal responses}

Filtration rate, foot activity and byssus thread production of different size groups of mussels were also studied in an effort to understand the sublethal effects of temperature on mussels. Each experiment was run using 10 replicates for each size group and temperature.

Filtration rate was measured following the method described by Coughlan (1969). The method is based on the absorption of neutral red by mussels from ambient water and rate of filtration was calculated using the following cquation (Coughlan, 1969):

$$
m=\frac{M}{n \cdot t} \ln \frac{C_{0}}{C_{t}}
$$

where, $M$ is the volume of the test solution, $n$ the number of animals used in the experiment, $t$ the time in hours, $C_{0}$ the initial concentration of the dye, $C_{r}$ the concentration of the dye at time $t$ and $m$ the rate of filtration in $\mathrm{ml} / \mathrm{h} / \mathrm{mussel}$.

For foot activity, at every $10 \mathrm{~min}$ for $12 \mathrm{~h}$, a note was made of the number of mussels with the foot extended outside the shell following procedures described by Holmes (1970). For each experiment, all foot activity readings were analyzed and percentage foot activity was calculated. Rate of byssus thread production was determined following the methods outlined by Winkle (1970) and Allen et al. (1976). Byssus threads produced by each mussel were counted after $12 \mathrm{~h}$ and expressed in threads/mussel/day.

\section{Statistical analysis}

The differences in physiological activity between control $\left(30^{\circ} \mathrm{C}\right)$ and experimental mussels were compared by ' $t$ ' tests (Sokal and Rohlf, 1981). A posteriori multiple comparisons of differences between size groups were done using Student-Neuman-Keuls (SNK) tests along with one-way ANOVA (Wilkinson, 1989).

\section{RESULTS}

\section{Mortality}

Significant size-dependent variation in the response of mussels was observed at all target temperatures (ANOVA, $P<0.0001$; Table 1), large mussels showing more tolerance than small mussels. At $44^{\circ} \mathrm{C}$, $100 \%$ mortality was achieved after $5 \mathrm{~min}$ in all size groups of mussels.

\section{Filtration rate}

The filtration rate of mussels showed a progressive decline at the higher temperatures (Table 2). For 
Table 1. Time to reach $100 \%$ mortality for various size groups of Perna indica to different temperatures

\begin{tabular}{lccccccc}
\hline \multicolumn{9}{c}{ Exposure time (hours) } \\
Temp & \multicolumn{7}{c}{ Size of the mussels (mm \pm SD) } \\
$\left({ }^{\circ} \mathrm{C}\right)$ & $8.9 \pm 0.6$ & $18.3 \pm 1.0$ & $25.5 \pm 1.7$ & $36.0 \pm 2.0$ & $d f$ & $F$ & $P$ \\
\hline 38 & $119 \pm 17$ & $134 \pm 20$ & $151 \pm 28$ & $173 \pm 25$ & 143 & 36.944 & $* * *$ \\
39 & $62 \pm 12$ & $87 \pm 16$ & $104 \pm 19$ & $121 \pm 15$ & 143 & 92.544 & $* * *$ \\
40 & $43 \pm 9$ & $62 \pm 18$ & $72 \pm 15$ & $94 \pm 10$ & 143 & 88.948 & $* * *$ \\
41 & $26 \pm 7$ & $44 \pm 10$ & $54 \pm 16$ & $63 \pm 12$ & 143 & 65.986 & $* * *$ \\
42 & $14 \pm 6$ & $24 \pm 5$ & $30 \pm 8$ & $33 \pm 11$ & 143 & 41.122 & $* * *$ \\
43 & $6 \pm 2$ & $10 \pm 4$ & $13 \pm 4$ & $14 \pm 6$ & 143 & 25.833 & $* * *$ \\
44 & $0 \pm 0$ & $0 \pm 0$ & $2 \pm 1$ & $5 \pm 2$ & 143 & 32.160 & $* * *$ \\
\hline
\end{tabular}

Values are expressed as mean $\pm \mathrm{SD}(n=36)$. One-way ANOVA followed by StudentNewman-Keuls (SNK) tests was used to determine whether differences between size groups were significant.

***Significant at $P<0.001$.

example, mussels in the $12 \mathrm{~mm}$ size group showed a filtration rate of $30 \mathrm{ml} / \mathrm{h} /$ mussel at $30^{\circ} \mathrm{C}$, reducing to $22 \mathrm{ml} / \mathrm{h} /$ mussel at $32.5^{\circ} \mathrm{C}$ and to $7 \mathrm{ml} / \mathrm{h} /$ mussel at $35^{\circ} \mathrm{C}$. This pattern of sharp decrease between 32.5 and $35^{\circ} \mathrm{C}$ was observed in all the size groups tested. A significant size-dependent variation in filtration rate (SNK tests, $P<0.05$ ) was observed; the large mussels showed a higher filtration rate.

\section{Foot activity}

At $30^{\circ} \mathrm{C}$, using the $9 \mathrm{~mm}$ size group, a highest foot activity of $47 \%$ was registered (Table 3 ). The reduction in foot activity was very sharp between 32.5 and $35^{\circ} \mathrm{C}$. Data also show a clear size-dependent variation in foot activity at 30 and $35^{\circ} \mathrm{C}$. However, no foot activity was observed at $37.5^{\circ} \mathrm{C}$ for all size groups.

\section{Byssus thread production}

A sharp decrease was recorded in the byssus thread production at $35^{\circ} \mathrm{C}$ (Table 4); indicating again that $32.5-35^{\circ} \mathrm{C}$ is the range of temperature within which physiological activities are critically affected in the brown mussels. Size-dependent variation in the rate of thread production was observed, with the rate of thread production decreasing with increasing shell

Table 2. Filtration rate of various size groups of mussels at different temperatures

\begin{tabular}{lcccccccc}
\hline & \multicolumn{9}{c}{ Filtration rate $(\mathrm{ml} / \mathrm{h} / \mathrm{mussel})$} \\
Temp & \multicolumn{9}{c}{ Size of the mussels $(\mathrm{mm} \pm \mathrm{SD})$} & & \\
$\left({ }^{\circ} \mathrm{C}\right)$ & $9.0 \pm 0.9$ & $18.7 \pm 2.1$ & $24.8 \pm 4.4$ & $31.5 \pm 3.2$ & $35.4 \pm 3.7$ & $d f$ & $F$ & $P$ \\
\hline 30.0 & $29.2 \pm 2.7$ & $30.2 \pm 2.7$ & $32.3 \pm 3.4$ & $33.1 \pm 1.8$ & $31.2 \pm 3.7$ & 49 & 2.878 & $*$ \\
32.5 & $22.2 \pm 1.8^{* * *}$ & $31.6 \pm 3.2^{\mathrm{Ns}}$ & $30.2 \pm 3.8^{\mathrm{NS}}$ & $31.5 \pm 4.0^{\mathrm{NS}}$ & $35.2 \pm 2.7^{\mathrm{NS}}$ & 49 & 22.538 & $* * *$ \\
35.0 & $7.1 \pm 2.2^{* * *}$ & $8.1 \pm 2.0^{* * *}$ & $9.7 \pm 1.1^{* * *}$ & $9.8 \pm 1.1^{* * *}$ & $10.0 \pm 1.8^{* * *}$ & 49 & 6.070 & $* * *$ \\
37.5 & $2.2 \pm 0.4^{* * *}$ & $3.3 \pm 0.8^{* * *}$ & $3.5 \pm 0.9^{* * *}$ & $4.0 \pm 0.2^{* * *}$ & $4.5 \pm 0.9^{* * *}$ & 49 & 23.486 & $* * *$ \\
\hline
\end{tabular}

Values are presented as mean $\pm \mathrm{SD}(n=10)$. Differences between control $\left(30^{\circ} \mathrm{C}\right)$ and experimental mussels are compared by ' $t$ ' tests and post hoc multiple comparisons of differences between size groups were done using one-way ANOVA and Student-Newman-Keuls (SNK) tests.

Levels of significance: $* P<0.05 ; * * P<0.01 ; * * * P<0.001 ;{ }^{\mathrm{NS}}$, not significant.

Table 3. Foot activity of various size groups of mussels at different temperatures

\begin{tabular}{|c|c|c|c|c|c|c|c|c|}
\hline \multirow{3}{*}{$\begin{array}{l}\text { Temp } \\
\left({ }^{\circ} \mathrm{C}\right)\end{array}$} & \multicolumn{5}{|c|}{ Foot activity $(\%)$} & \multirow[b]{3}{*}{$d f$} & \multirow[b]{3}{*}{$F$} & \multirow[b]{3}{*}{$P$} \\
\hline & \multicolumn{5}{|c|}{ Size of the mussels $(\mathrm{mm} \pm \mathrm{SD})$} & & & \\
\hline & $9.3 \pm 0.3$ & $18.4 \pm 0.9$ & $24.2 \pm 1.9$ & $31.0 \pm 2.1$ & $36.2 \pm 4.9$ & & & \\
\hline 30.0 & $46.9 \pm 8.4$ & $40.8 \pm 7.0$ & $39.0 \pm 7.4$ & $35.3 \pm 7.2$ & $35.2 \pm 6.4$ & 49 & 4.308 & ** \\
\hline 32.5 & $32.4 \pm 7.0^{* * *}$ & $35.1 \pm 5.1^{*}$ & $35.0 \pm 6.2^{\mathrm{NS}}$ & $30.7 \pm 6.5^{\mathrm{NS}}$ & $27.9 \pm 5.1 *$ & 49 & 2.536 & NS \\
\hline 35.0 & $4.5 \pm 3.6^{* * *}$ & $8.3 \pm 3.1^{* * *}$ & $8.6 \pm 4.0^{* * *}$ & $9.3 \pm 4.7^{* * *}$ & $9.1 \pm 3.1 * * *$ & 49 & 2.684 & * \\
\hline 37.5 & $0 \pm 0^{* * *}$ & $0 \pm 0 * * *$ & $0 \pm 0^{* * *}$ & $0 \pm 0^{* * *}$ & $0 \pm 0^{* * *}$ & - & - & - \\
\hline
\end{tabular}

Values are presented as mean \pm SD $(n=10)$. Statistical analysis as in Table 2 .

Levels of significance: * $P<0.05$; ${ }^{* *} P<0.01$; ${ }^{* * *} P<0.001$; ${ }^{\text {Ns }}$, not significant. 
Table 4. Byssus thread production of various size groups of mussels at different temperatures

\begin{tabular}{lcccccccc}
\hline \multicolumn{7}{c}{ Byssus thread production (threads/mussel/day) } \\
\cline { 2 - 9 } Temp & \multicolumn{7}{c}{ Size of the mussels $(\mathrm{mm} \pm \mathrm{SD})$} & \\
$\left({ }^{\circ} \mathrm{C}\right)$ & $9.1 \pm 0.5$ & $18.7 \pm 1.7$ & $24.5 \pm 2.0$ & $31.7 \pm 4.9$ & $35.8 \pm 3.2$ & $d f$ & $F$ & $P$ \\
\hline 30.0 & $15.4 \pm 7.0$ & $13.9 \pm 5.5$ & $13.7 \pm 5.3$ & $9.8 \pm 7.4$ & $8.4 \pm 3.4$ & 49 & 2.649 & $*$ \\
32.5 & $10.3 \pm 7.7^{\mathrm{NS}}$ & $8.9 \pm 3.8^{*}$ & $8.4 \pm 6.0^{*}$ & $8.4 \pm 5.8^{\mathrm{NS}}$ & $7.2 \pm 5.6^{\mathrm{NS}}$ & 49 & 0.386 & NS \\
35.0 & $0 \pm 0^{* * *}$ & $1.9 \pm 0.5^{* * *}$ & $1.4 \pm 0.7^{* * *}$ & $1.7 \pm 0.5^{* *}$ & $3.1 \pm 1.4^{* * *}$ & 49 & 22.034 & $* * *$ \\
37.5 & $0 \pm 0^{* * *}$ & $0 \pm 0^{* * *}$ & $0 \pm 0^{* * *}$ & $0 \pm 0^{* * *}$ & $0 \pm 0^{* * *}$ & - & - & - \\
\hline
\end{tabular}

Values are presented as mean $\pm \mathrm{SD}(n=10)$. Statistical analysis as in Table 2 .

Levels of significance: ${ }^{*} P<0.05{ }^{* *} P<0.01 ;{ }^{* * *} P<0.001$; ${ }^{\text {NS }}$, not significant.

size of mussels. Foot activity and byssus thread production of mussels were strongly correlated $\left(r^{2}=0.86, \quad P<0.0001\right)$ at different sublethal temperatures.

\section{DISCUSSION}

Experimental work on the thermal tolerance of Mytilus edulis L, along with field trials at the Redondo Beach power station, California (Fox and Coheran, 1957) showed that $M$. edulis could be controlled at a temperature of $43^{\circ} \mathrm{C}$, maintained for $2 \mathrm{~h}$ once every 4 weeks during spatfall. The present studies showed that $100 \%$ kill of all size groups of brown mussels could be achieved by raising the temperature to $38^{\circ} \mathrm{C}$ and maintaining that temperature level for about $3 \mathrm{~h}$ (Table 1). At San Onofre power station (SONGS), California, heat treatment for $2 \mathrm{~h}$ at $38^{\circ} \mathrm{C}$, once every 6 weeks is successfully used to control mussel fouling in the cooling conduits (Stock and Strachan, 1977). At Eems power station, The Netherlands, a temperature of $38^{\circ} \mathrm{C}$ is used for 1 h to ensure $100 \%$ mortality of $M$. edulis; it was also reported that this treatment is more economical and less damaging to the environment than continuous chlorination (Jenner, 1982). The average ambient seawater temperature at these power plants (SONGS and Eems) ranges from $18-21^{\circ} \mathrm{C}$ during summer (Stock and Strachan, 1977; Jenner, 1982) and to achieve $100 \%$ mortality of the mussels at $38^{\circ} \mathrm{C}$, the intake water has to be heated by $17-20^{\circ} \mathrm{C}$. It should be noted that the average intake water temperature at MAPS, Kalpakkam ranges from $27^{\circ} \mathrm{C}$ (winter) to $31^{\circ} \mathrm{C}$ (summer). Therefore, the energy required to raise the water temperature to the desired level $\left(38^{\circ} \mathrm{C}\right)$ is correspondingly less $\left(7-11^{\circ} \mathrm{C}\right)$. Thus, it is logical to presume that the heat treatment method reportedly successful at SONGS and Eems power stations would be more economical if practised in the tropics.

Mussels in general respond to sudden changes in temperature by closing their shells. Trueman and Lowe (1971) suggested that temperature sensitive receptors on the mantle cavity might be responsible for shell closure in mussels. The period for which they remained closed could last for many days, with only short and intermittent periods of shell opening at sublethal temperatures (Widdows, 1973). However, at lethal temperatures, mussels are forced to shut

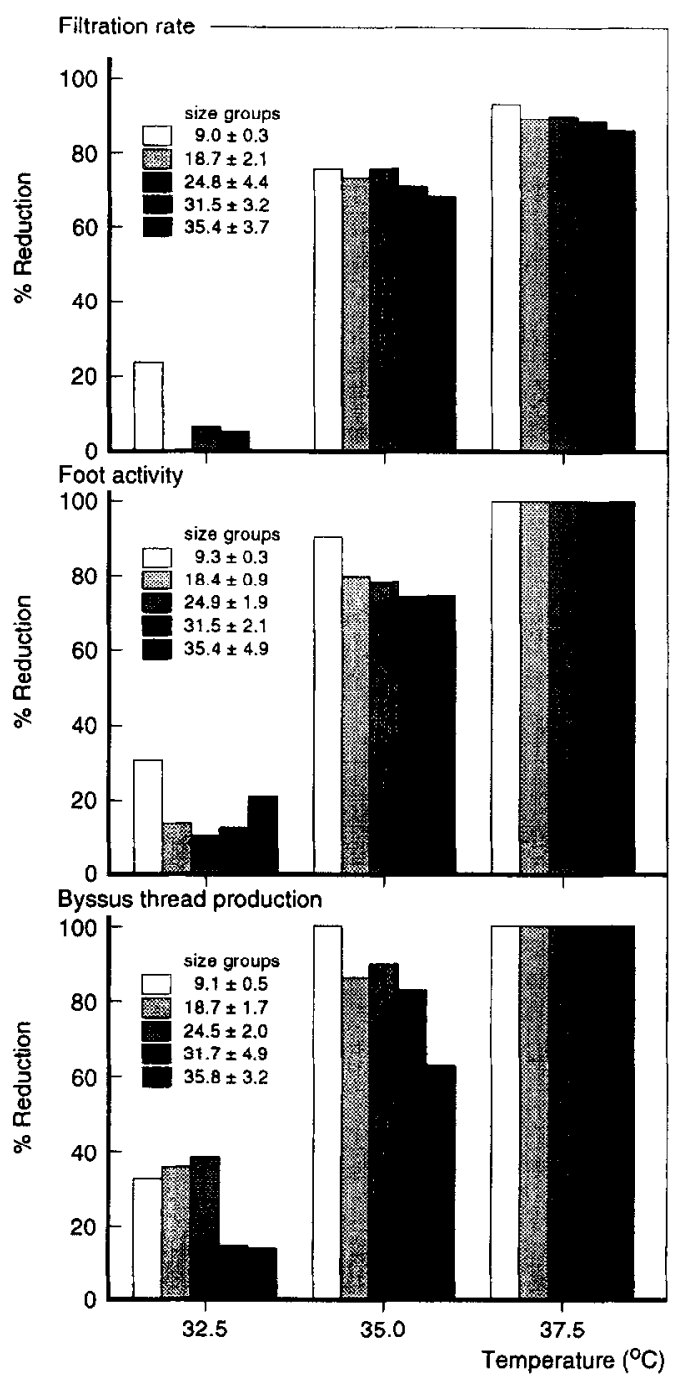

Fig. 1. Percentage reduction in filtration rate, foot activity and byssus thread production of various size groups of brown mussels at different temperatures when compared to $30^{\circ} \mathrm{C}$ (control). 


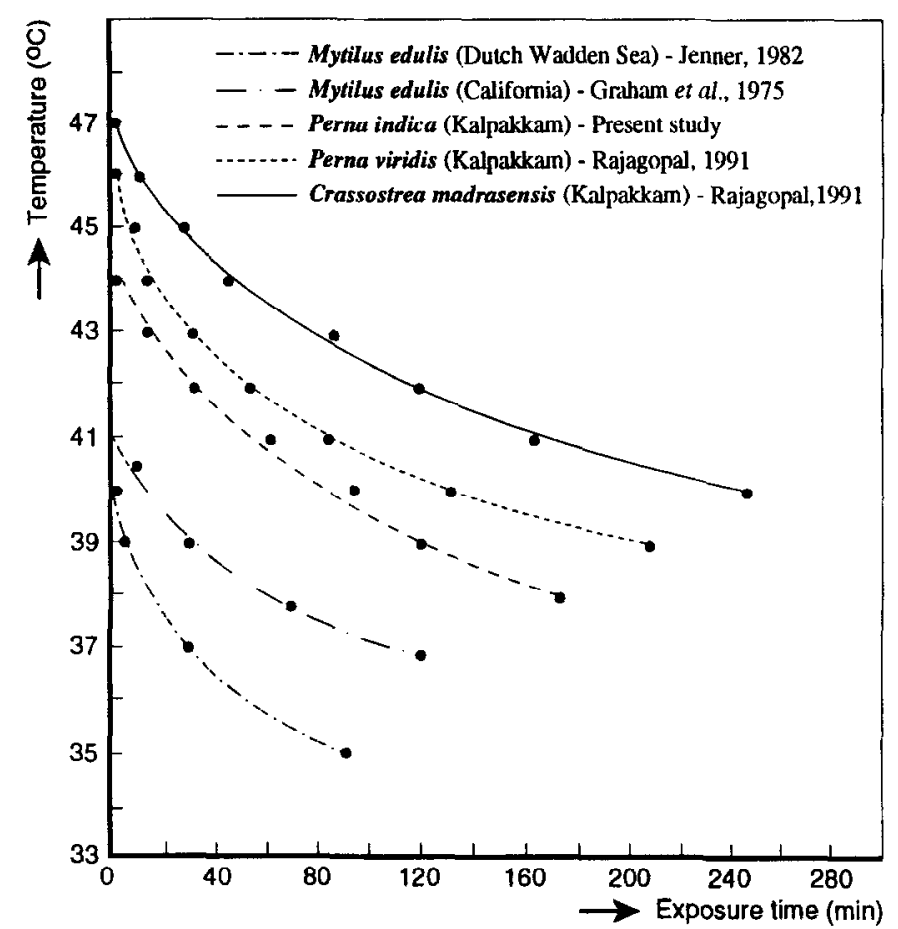

Fig. 2. Comparison of time to $100 \%$ mortality over a range of temperatures for the brown mussel, Perna indica, green mussel, Perna viridis and oysters, Crassostrea madrasensis at Kalpakkam along with published results for blue mussel, Mytilus edulis from Californian coastal waters (Graham et al., 1975) and Dutch Wadden Sea (Jenner, 1982).

their valves and exist on stored food reserves and anaerobic respiration, until energy resources are depleted or metabolic wastes reach a toxic level (Bayne et al., 1976).

In the present study, physiological activities such as filtration rate, foot activity and byssus thread production were significantly reduced $(P<0.001)$ when the temperature was over $32.5^{\circ} \mathrm{C}$. Gonzalez and Yevich (1976) also observed that higher temperature causes a reduction in the feeding rate, which could be attributed to the degeneration of the gill filaments and histological changes in the stomach and intestine. Read (1962) demonstrated that the weight specific respiration rate of large mussels decreased appreciably at higher temperatures, the probable reason again being gill damage as mentioned above. Histological studies by Gonzalez and Yevich (1976) also showed that at higher temperatures the formation of byssus threads in $M$. edulis was weak and irregular. The present study has indicated that at higher temperatures $\left(>35^{\circ} \mathrm{C}\right)$ byssus thread production of $P$. indica is completely stopped. Moreover, a higher percentage of reduction of physiological activities was observed in young mussels (Fig. 1). It is well known that young mussels are more active than older ones and they have relatively high metabolic rates (Bayne et al., 1976). Therefore, under stress, juveniles might react more rapidly than larger mussels.
The exposure time required for $100 \%$ mortality of $P$. indica to different target temperatures (Fig. 2) is shorter than that reported for $P$. viridis and Crassostrea madrasensis Preston (Rajagopal, 1991). The last two species are commonly found in backwaters and coastal waters (Rajagopal et al, 1990) whereas $P$. indica is a marine species (Kuriakose, 1980). As there is greater temperature natural variation in backwaters compared with the marine environments, the temperature tolerance among these bivalves may be related to habitat differences (Bayne et al., 1976; Wright et al., 1983).

Comparisons of mortality between size groups show that large mussels are more tolerant than smaller ones. Wallis (1975) has suggested that metabolic rates which vary with age or size of the mussels are the causative factors for the differences. Thus, at any lethal temperature, smaller mussels will succumb more quickly than larger mussels. The significance of this observation is that heat treatment could be more economically employed following peak breeding periods when young brown mussels are encountered in the cooling conduits as the time required to kill them would be shorter.

Heat treatment appears to be a viable method for mussel control in tropical power stations. It would also be relevant to study its synergistic efficiency when used with other control methods such as 
chlorination or osmotic shock. It is possible that this combination of treatments may result in mussel control at much lower temperatures and shorter exposure times than the results of the present study would indicate.

Acknowledgements--The authors are thankfal to Dr P. N Moorthy, Head, APCD/BARC, Bombay and Dr P. K. Mathur, Head, WSCL/IGCAR, Kalpakkam for providing facilities and encouragement. Thanks are due to Madras Atomic Power Station authorities for facilities at the plant site. Financial support to S.R. from Council of Scientific and Industrial Research, New Delhi is gratefully acknowledged. Special thanks to Dr Henk Jenner, Section Manager, KEMA Environmental Research, The Netherlands and Professor G. van der Velde, Department of Aquatic Ecology, University of Nijmegen, The Netherlands for critically going through the manuscript and offering valuable comments.

\section{REFERENCES}

Allen J. A., Cook M., Jackson D. J., Preston S. and Worth E. M. (1976) Observation on the rate of production and mechanical properties of the byssus threads of Mytilus edulis L. J. Moll. Stud. 42, 279-289.

Bayne B. L., Thompson R. J. and Widdows J. (1976) Physiology. In Marine Mussels: Their Ecology and Physiology (Edited by Bayne B. L.), pp. 121-206. Cambridge University Press, Cambridge.

Brungs W. A. (1977) General considerations concerning the toxicity to aquatic life of chlorinated condenser effluent. In Biofouling Control Procedures: Technology and Ecological Effects (Edited by Jensen L. D.), pp. 109-113. Marcel Dekker Inc., New York.

Burton D. T. and Liden L. H. (1978) Biofouling control alternatives to chlorine for power plant cooling water systems: an overview. In Water Chlorination, Environmen tal Impact and Health Effects (Edited by Jolly R. L., Gorchev H. and Hamilton D. H.), Vol. 2, pp. 717-735. Ann Arbor Science Publishers, Ann Arbor, MI.

Claudi R. and Mackie G. L. (1994) Practical Manual for Zebra Mussel Monitoring and Control, pp. 1-227. Lewis Publishers, London.

Coughlan J. (1969) The estimation of filtering rate from the clearance of suspensions. Marine Biol. 2, 356-358.

Fox D. L. and Coheran E. F. (1957) Thermal and osmotic counter measures against some typical marine fouling organisms. Corrosion 14, 31-32.

Gonzalez J. G. and Yevich P. (1976) Responses of an estuarine population of the blue mussel Mytilus edulis to heated water from steam generating plant. Marine Biol. 34, 174-189.

Graham J. W., Monereiff R. M. and Benson P. H. (1975) Heat treatment for the control of marine fouling at coastal electric generating stations. IEEE Oceans, 926-930.

Holmes N. J. (1970) The Effects of Chlorination on Mussels, Report No. RD/L/R 1672, pp. 1-20. Central Electricity Research Laboratories, Leatherhead, Surry.

Imbro E. V. and Gianelli J. M. (1982) Report on Service Water System of Flow Blockages by Bivalve Mollusks at
Arkansas Nuclear one and Brunswich, pp. I 35. U.S. Nuclear Regulatory Commission, Washington.

Jenner H. A. (1982) Physical methods in the control of mussel fouling in seawater cooling systems. La Tribune du CEBEDEAU 35, 287-291.

Jenner H. A. (1983) Control of mussel fouling in The Netherlands: experimental and existing methods. In Condenser Macrofouling Control Technologies (Edited by Tous I. A. D., Miller M. J. and Mussalli Y. G.), pp. 1-11. Electric Power Research Institute, Hyannis, MA.

Jenner H. A. (1985) Chlorine minimization in macrofouling control in the Netherlands. In Water Chlorination, Environmental Impact and Health Effects (Edited by Jolly R. L., Bull R. J., Davies W. P., Katz S., Roberts M. H. and Jacobs V. A.), Vol. 5. pp. 1425-1433. Lewis Publishers Inc., MI.

Jenner H. A and Janssen-Mommen P. M. (1993) Monitoring and control of Dreissena polymorpha and other macrofouling bivalves in The Netherlands. In Zebra Mussels; Biology, Impacts and Control (Edited by Nelepa T. F. and Schloesser D. W.), pp. 537-555. Lewis Publishers, London.

Kuriakose P. S. (1980) Mussels (Mytilidae: Genus Perna) of the Indian coast. In Coastal Aquaculture: Mussel Farming, Progress and Prospects (Edited by Nayar K. N., Mahadevan S., Alagarswami K. and Meenakshisundaram P. T.), pp. 1-5. CMFRI Bulletin 29, Indian Council of Agricultural Research, Cochin.

Nair K. V. K. (1990) Marine biofouling and allied problems in the condenser cooling system of MAPS. In Marine Biofouling and Power Plants (Edited by Nair K. V. K. and Venugopalan V. P.), pp. 92-103. Bhabha Atomic Research Centre, Bombay.

Neitzel D. A., Johnson K. I., Page T. L., Young J. S. and Daling P. M. (1984) Correlation of bivalve biological characteristics and service water system design. In Bivalve Fouling of Nuclear Power Plant Service Water Systems, Vol. 1, pp. 1-119. U.S. Nuclear Regulatory Commission, Washington

Rajagopal S. (1991) Biofouling problems in the condenser cooling circuit of a coastal power station with special reference to green mussel, Perna viridis (L.), Ph.D. thesis, pp. 1-113. University of Madras, India.

Rajagopal S., Azariah J. and Nair K. V. K. (1990) Ecology of fouling organisms in Edaiyur backwaters, Kalpakkam. Mahasagar, Bull. Natn. Inst. Oceanogr. 23, 29-4I.

Rajagopal S., Sasikumar N., Azariah J. and Nair K. V. K. (1991a) Some observations on biofouling in the cooling water conduits of a coastal power plant. Biofouling 3, 311-324.

Rajagopal S., Venugopalan V. P., Nair K. V. K. and Azariah J. (1991b) Biofouling and its control in a tropical coastal power station: a case study. Biofouling 3, 325-338.

Read K. R. H. (1962) Respiration of the bivalve molluscs Mytilus edulis L. and Brachidontes demissus plicatulus Lamarck as a function of size and temperature. Comp. Biochem. Physiol. 7, 89-101.

Sasikumar N., Nair K. V. K. and Azariah J. (1992) Response of barnacles to chlorine and heat treatment: an experimental study for power plant biofouling control. Biofouling 6, 69-79.

Smith A. P. and Kretschner T. R. (1984) Electrochemical control of fouling. In Marine Biodeterioration: An Interdisciplinary Study (Edited by Costlow J. D. and Tipper R. C.), pp. 250-254. Naval Institute Press, Annapolis, MD. 
Sokal R. R. and Rohlf F. J. (1981) Biometry, pp. 1-859. W. H. Freeman and Company, New York.

Stock N. J. and Strachan A. R. (1977) Heat as a marine fouling control process at coastal electric generating stations. In Biofouling Control Procedure: Technology and Ecological Effects (Edited by Jensen L. D.), pp. 55-62. Marcel Dekker Inc., New York.

Strauss S. D. (1989) New methods, chemicals improve control of biological fouling. Power, 51-52.

Trueman E. R. and Lowe G. A. (1971) The effect of temperature and littoral exposure on the heart rate of a bivalve mollusc, Isognomon alatus, in tropical conditions. Comp. Biochem. Physiol. 38, 555-564.

Wallis R. L. (1975) Thermal tolerance of Mytilus edulis of Fastern Australia. Marine Biol. 30, 183-191.

Widdows J. (1973) The effects of temperature on the metabolism and activity of Mytilus edulis L. Neth. J. Sea Res. 7, 387--398.

Wilkinson L. (1989) Systat: The System for Statistics. Systat Inc., Evanston, IL.

Winkle W. V. (1970) Effects of environmental factors on byssal thread formation. Marine Biol. 7, 143-148.

Wright D. A., Kennedy V. S., Roosenburg W. H., Castagna M. and Mihursky J. A. (1983) Temperature tolerance of embryos and larvae of five bivalve species under stimulated power plant entrainment conditions: a synthesis. Marine Biol. 77, 271-278. 